\title{
Pharmaceutical care in the treatment of pediatric asthma: the role of community pharmacist
}

\author{
Katerina Iliovska*, Zoran Sterjev, Aleksandra Kapedanovska Nestorovska \\ Faculty of Pharmacy, Ss. Cyril and Methodius University, Majka Tereza 47, 1000 Skopje, \\ Republic of North Macedonia
}

Received: May 2019; Accepted: January 2020

\begin{abstract}
Asthma is one of the leading chronic diseases in the pediatric population affecting 1 out of every 12 school-aged children. It has a significant contribution to the growing prevalence in prescribed medications. The symptoms of pediatric asthma are often variable. Pharmacotherapy is dominant modality in the treatment of asthma. Safe and effective treatment is still a challenge for all caregivers, including pharmacists. Taking into account the increasing global burden of asthma, pharmacists are ideally positioned to contribute in asthma management. The concept of pharmaceutical care implies achieving an optimal therapeutic outcome and improving patient's quality of life through the promotion of rational drug use.

The aim of this article is to give an overview of published data emphasizing to the need of implementation of pharmaceutical care services in the treatment of childhood asthma and the significant aspects of pediatric asthma medication therapy management in community pharmacy.
\end{abstract}

Keywords: asthma, pediatric population, community pharmacist, pharmaceutical care

\section{Background}

Asthma is a heterogeneous chronic airway disease very common in childhood, which is characterized by respiratory symptoms, including wheezing, breathlessness, chest tightness and cough, with variable expiratory airflow obstruction. The pathophysiology of asthma integrates persistent, but therapeutically modifiable inflammation and bronchial hyperresponsiveness (BHR, i.e. increased sensitivity to bronchoconstrictor stimuli). Pharmacoepidemiological studies strongly substantiate the concept of genetic predisposition in the development of asthma. Exacerbation of asthma can be provoked by multiple trigger factors, including allergens, airborne irritants, viral respiratory infections, exposure to tobacco smoke, obesity, stress and occupational exposure. Exposure to triggers can result in inflammation, BHR, airflow obstruction, bronchospasm, respiratory symptoms, and asthma attacks, particularly in those with uncontrolled or under-treated asthma.

Asthma prevalence is increased in populations that adopt Western lifestyle and become urbanized. 250000 people die from asthma each year, accounting for 1 in every 250 deaths worldwide. The increasing of prevalence is ranged from 3 to 5\% in developing countries and above 20\% in developed countries, affecting people of all ages. Even though, there are reports of a reduction in hospitalization and death rates in recent years, for many economically developed countries, the improvements seen over the last decades of the twentieth century have stagnated in the new millennium (Holgate et al., 2017).

\footnotetext{
*iliovska.katerina@gmail.com
} 
Table 1. Basic characteristics of good national strategy towards better measurements of the true burden of asthma, improving access to health care and improving adherence to asthma management*

1. Early diagnosis and initiation of first line therapy (anti inflammatory drugs)

2. Improving a long-term asthma control

3. Offering a simple program for self-management and prevention of asthma exacerbation

4. Effective education for health care providers

*Global Asthma Network, 2014

Appropriate pharmacological treatment and proper patient counseling are crucial for achieving control of symptoms. However, although the majority patients enrolled in clinical trials are able to achieve high levels of asthma control with pharmacotherapy, in "real life" as it is shown in surveys, most of patients continue to suffer significant levels of poorly controlled symptoms, asthma exacerbations, over-reliance on rescue bronchodilators and impairment of quality of life. Asthma exacerbations are mostly due to poorly managed disease that is related to poor treatment adherence, poor inhaler technique etc., or to biologically severe, drug-resistant disease. Exacerbations impose a need for additional medication and, if severe enough, urgent medical attention. All of this leads to increased social and health care costs and has a significant impact on patients and their families by affecting their quality of life. The disability-adjusted life years (DALY) lost due to asthma is estimated at 15 million per year, which equates to $1 \%$ of total global health impairment (Holgate et al., 2017).

The economic burden of the asthma, due to direct costs of the disease (healthcare services, medicines) and indirect costs (costs to society, loss of work productivity of patients and their caregivers) is estimated at $€ 19.3$ billion during 1999-2002 for people aged 15-64 years living in Europe (Global Asthma Network, 2014). Since, economic costs associated with uncontrolled or poorly controlled asthma can be defined as preventable and modifiable, significant overall cost-cutting can be achieved with systematic strategies for establishing an optimal asthma control. The basis in asthma burden reduction is in the implementation of optimal standards for health care in everyday practice. The need of creating national strategies whose benefits can be reflected in reduction of physical and emotional suffering of patients, as well as reduction in costs in health care system has been emphasized in The Global Asthma Report (Global Asthma Network, 2014). National strategies for managing asthma should: 1) raise awareness among patients, health professionals, and the public, that asthma is a serious chronic condition, 2) ensure the recognition of the signs and symptoms of asthma by patients, families, and the public, 3) to establish an appropriate diagnosis by health professionals, 4) ensure effective control of asthma by encouraging a partnership among patients, physicians, and other health professionals through modern treatment and education programs, and 5). enhance the quality of life for patients with asthma, reduce the burden of asthma, and decrease asthma-related deaths. The characteristics of good national strategy, as well as the barriers of its implementation, are summarized in Table 1 and 2.

\section{Asthma in pediatric population}

Over the past decades, asthma morbidity has increased worldwide, and according to data provided by World Health Organization, it is the most prevalent disease in childhood (World Health Organization, 2017). Childhood asthma prevalence increased remarkably in Europe in the second half of the twelfth century. Published studies of asthma epidemiology in children, performed in Norway have shown an increase in prevalence from $0.4 \%$ in the 1940 s to $12.3 \%$ in $1990 \mathrm{~s}$. An increase in the prevalence of $20 \%$ was observed in 2004 , even though the most recent study reported a decline to $17.6 \%$.

Table 2. Barriers of implementation of a strategy*

1. Reduced rate of implementation of guidelines for prevention and management

2. Reduced rate of implementation of education programs and training for health care providers

3. Poor access and/or availability of inhaled corticosteroids

4. Misdiagnosis/underdiagnosis and inappropriate treatment

*Global Asthma Network, 2014

Maced. pharm. bull., 66 (1) 15 - 24 (2020) 
The increase in prevalence was initially identified as evident in Western Europe with an increasing rate from East to West Europe. The International Study of Asthma and Allergies in Childhood: ISAAC study (European Respiratory Society, 2019) which was aimed to evaluate the childhood asthma prevalence in Europe, point to lifetime prevalence of asthma ranging from 1.6 to $20.7 \%$ for 13-14 year-old children in Albania and UK, respectively; and a progressive trend in prevalence ranging from 1.4 to $20.9 \%$, observed in Estonia and UK, respectively, for 6-7-year-old children.

It is important to note that underlying causes, prevalence and clinical presentation are variable with age. Asthma usually begins in early childhood, although asthma symptoms may later recur. $95 \%$ of the patients who suffer from asthma have their first episode of wheezing before the age of 6 years. A US study demonstrated the decreasing trend of asthma incidence in correlation with growth and development: from $3 \%$ in the first year of life, to $0.9 \%$ in the age group 1 to 4 years, and to $0.1 \%$ after the age of 15 years. Another cohort study conducted in New Zealand found that $27 \%$ of all children at age of 9 years had a history of at least one episode of wheezing, and $4.2 \%$ were receiving asthma therapy. The results are similar in US and Australian cohort studies; in all, the incidence of wheezing was greatest in the first years of life and leveled off in the adolescence (Holgate et al., 2017).

The asthma management in the pediatric population is a complex process which requires high expertise, multidisciplinary approach and responsibility for mutual collaboration between health care providers and patients involved in the overall process. Change in the paradigm that children are small adults is of imperative significance. Understanding the variation in pharmacokinetic and pharmacodynamic parameters associated with continuous growth and development of the child, the importance of dose calculations based on weight and body surface, frequent changes in available pharmaceutical dosage forms to make them suitable for use by children, as well as the various aspects of providing educations for children and their caregivers are of essential importance in providing an optimal healthcare for pediatric population (Bhatt-Mehta et al., 2012).

\section{Pediatric asthma medication therapy management in community pharmacy}

Pharmaceutical Care is a patient-centered, outcomes oriented pharmacy practice that requires the pharmacist to work in concert with the patient and the patient's other healthcare providers to promote health, to prevent disease, and to assess, monitor, initiate, and modify medication use to assure that drug therapy regimens are safe and effective. The goal of Pharmaceutical Care is to optimize the patient's health-related quality of life, and achieve positive clinical outcomes, within realistic economic expenditures. In that manner, pharmacists are recognized as accessible healthcare practitioners who may help patients who suffer from asthma, to achieve better control of their disease trough education and medication management (Almomani et al., 2017; Benavides et al., 2009; Bradley et al., 2016; Fraeyman et al., 2017; Okelo et al., 2013; Pooripussakul et al., 2013). Pharmaceutical Care in the asthma management involves: 1) education regarding to the medication therapy and the importance of the medication adherence, 2) choosing an optimal inhaler device for children with asthma, 3) identification and prevention of the potential and actual medical errors leading to worsening of symptoms, and 4) evaluation of the therapeutic outcomes.

Variability in treatment outcome and adherence among children with asthma is significant. In that manner, it is of a great importance to point out the fact, that children are not small adults and the safety of the medicine use must not be presumed. Community pharmacist can provide patient individualized counseling on self-management for disease, which integrates the patient education at every visit to the pharmacy. Patient education and counseling has to be focused on recognition of poorly controlled asthma symptoms, and symptoms of exacerbation, providing written management plans, as well as identification and avoiding trigger factors. Appropriate education for children and parents contributes to the reduction of hospital admissions and admissions at emergency departments (Turner et al., 2016). National Asthma Education and Prevention Program (NAEPP) outlines the specific evidence-based recommendations regarding management of childhood asthma (National Asthma Education and Prevention Program, 2002). According to NAEPP, patient education must integrate: 1) detailed instructions regarding selfrecognition of symptoms and signs of asthma exacerbation, which will reflect improving in knowledge of an optimal asthma control, and 2) identification of all trigger factors and construction of a strategy for their better recognition and avoidance. Also, it is crucial for the pharmacist to offer an individualized asthma management plan, to adjust the asthma treatment according to the patient needs and to integrate the education at every pharmacy visit, to determine whether, the use of inhaler device and inhalation technique are adequate and to offer detailed instructions regarding proper use of these devices, and last but not least, to establish long-term asthma management, with asthma control, as the main goal.

Greater awareness of these important factors and greater partnership with child's parents (including wider use of self-management education) is a challenge for community pharmacist as primary care asthma providers. 
Long-term asthma management and prevention in pediatric population

For most favorable therapeutic outcomes, it is essential that pharmacists provide information about the effects of prescribed drug, dose and dosage regimen, the difference between asthma relievers and long-term control medications, the effects of concomitant medication use and potential adverse reactions/events. As with adults, evidence-based approach for long-term asthma control in pediatric patients is use of long-acting $\beta_{2}$ agonists in addition to inhaled corticosteroids, to address the bronhoconstriction of airways and the underlying inflammation. This approach is based on the hypothesis that increasing the dose of anti-inflammatory agent will successfully control the increased asthma severity. Longterm control medications are taken on a regular basis in order to achieve and maintain control of symptoms. Rescue or reliever medications produce rapid reversal of acute airflow obstruction and quick relief of asthma symptoms (wheezing, coughing, shortness of breath etc.). Corticosteroids are effective in both long-term asthma control and relieving symptoms in exercise-induced asthma or acute exacerbation of asthma. Treatment of acute exacerbations of asthma symptoms integrates the use of short-acting $\beta_{2}$-agonists on an as-needed basis. Inhalation is the preferred route of administration. Therapy should be maintained for 3 to 6 months once asthma symptoms have been controlled, after which "stepdown" of asthma treatment is considered. When considering any step-down of asthma treatment, the therapeutic outcome has to be evaluated in accordance to control of symptoms, lung function and frequency of exacerbations of the individual patient. Prescribing controller therapy during specific seasons or exposures should be considered. For instance, in children who experience acute exacerbations of symptoms triggered by viral infections, step-up approach at specific high-risk times of the year (school attendance) or other social situations (day-care settings) may be appropriate.

Patient education regarding the overall management plan and avoidance of the previously identified trigger factors has to be discussed at every step of the pharmaceutical care process (Holgate et al., 2017). Maintenance of optimal asthma control in children and infants requires four components: 1) assessment and monitoring, 2) education, 3) control of triggers (avoidance of environmental factors and treatment of comorbid conditions), and 4) pharmacologic therapy. The treatment has to be individualized to the needs, circumstances, and responsiveness of the patient. While monitoring asthma treatment, pharmacists should promote rational drug use by establishing the frequency of asthma exacerbations and the related use of short-acting $\beta_{2}$ agonists (relievers). Several guidelines are available to support health care professionals on asthma management for children: 1) Pocket Guide for asthma management and prevention in children 5 years and younger (Global Initiative for Asthma, 2015), and 2) Pocket Guide for asthma management and prevention for adults and children older than 5 years (Global Initiative for Asthma, 2017).

\section{Making an optimal choice of inhaler device for children with asthma}

Asthma medications are formulated as disperse systems in specific containers. The container is specifically designed to generate nebules and/or aerosols. Precise and sophisticated devices for administration via inhalation are: nebulizers, pressure metered - dose inhaler (pMDI), dry powder inhalers (DPI) and soft mist inhaler (SMI). Inhaler devices are often used plus spacer, regarding the avoidance of difficulties with coordination of actuation and inhalation in children. A spacer is a large, mostly plastic container with a mouthpiece and a hole for the aerosol inhaler.

Rescue medications for treatment of acutely worsened symptoms and long-term controller medications for management of symptoms on regular basis, both are formulated as aerosolized medications. Often, therapy may involve use of two or more types of inhalers, but in order to facilitate the management, use of the same type of device for all aerosolized medications has been recommended (for instance pMDI or nebulizer as rescue and controller therapy) (Barrons et al., 2015).

Table 3. Making an optimal choice of inhaler device for children with asthma based on efficacy of drug delivery, cost effectiveness, safety, ease of use, and convenience*

\begin{tabular}{lll}
\hline \hline Age group & Preferred device & Alternate device \\
\hline Younger than 4 years & pMDI plus dedicated spacer with face mask & Nebulizer with face mask \\
4-6 years & pMDI plus dedicated spacer with mouthpiece & Nebulizer with mouthpiece \\
& DPI, or breath-actuated pMDI, or pMDI with spacer & Nebulizer with mouthpiece \\
Older than 6 years & and mouthpiece & \\
\hline
\end{tabular}

* Global Initiative for Asthma, 2006 
In the process of making an optimal selection for an inhaler device (Table 3), it is necessary to account for the device availability of rescue and controller medications, patient's age, ability, preferences, and costs. Usage of colored inhaler devices, and face masks with attractive design (different colors or favorite cartoon characters) is preferred in young children in order to facilitate the drug administration. Selection of a single inhaler format may facilitate the patient teaching, and reduce the confusion regarding to the different inhalation techniques required by different inhaler devices (Barrons et al., 2015). The use of multiple inhalers is associated with significantly increased risk of incorrect technique in comparison with the use of a single inhaler (Khassawneh et al., 2008).

\section{Inhaler technique education in pediatric patients}

Pharmacists should be aware that poor inhaler technique can lead to uncontrolled or poorly controlled asthma. The risk of inadequate use of inhaler device or inhalation technique among children with asthma is incredibly big and usually leads to suboptimal asthma control or medication overuse. In a matter of the fact, it is necessary to overcome all the potential barriers and establish communication between the health care provider and the child's parents which will facilitate parents' perception of the disease and treatment goals in order to enable successful management and disease control. A brief education regarding the correct use of inhaler device can improve the patient's inhaler technique. The training performed by a health care professional must include a physical demonstration and evaluation of the patient's technique thereupon. Community pharmacists can provide effective brief training in the correct inhaler technique and in the care and cleaning of both, inhaler and spacer. These interventions can improve measures of asthma control and lung function measures. In order to maintain a correct inhaler technique, education and training, and evaluation of patient's inhaler technique should be performed at every patient visit. But, even after the provided training, some patients will continue to have difficulties while using inhalers properly. And patients who are able to demonstrate correct technique during consultation with a health professional may not maintain at other times.

Systematic reviews, focused on identification of the most common errors in asthma treatment, emphasize the poor inhaler technique, errors in preparation of the inhaler device, inability to coordinate the actuation and inhalation (in case when spacer isn't used), inability to hold breath long enough and fast breathing (Ibrahim et al., 2015). Other important reason which contribute to suboptimal outcomes in asthma relate to the poor therapy adherence and compliance. Variability in treatment adherence among children with asthma is significant. And sometimes, different asthma medications can be administered via different inhaler devices, and often, the inhaler technique specificities are likely to be confusing for many patients. Incorrect use of inhalers may lead to insufficient drug delivery to the lower airways, increased drug deposition to the upper airways, and contributes to the risk of drug associated local adverse reactions, worsened asthma control, frequent asthma instability, subsequently increased reliever uses and increased use of emergency medical services.

Knowledge of the pharmaceutical and technological characteristics of a drug formulation, the anatomy and physiology of the lungs, the physical processes of particle deposition in the airways and the target site of action are a crucial basis for understanding the disposition of the drug in the lungs and further patient education. Observing the influence that breathing (inhaling and exhaling) has on the process of disposition of a drug in the lungs, is a crucial step in order to determine, if the drug will reach the site of action, although these processes are susceptible to intra- and inter-individual variability. Training regarding preparation of a new spacer before its use, as well is a critical step in the overall proper use of an inhaler device. The electrostatic charge of a plastic spacer significantly reduces the fraction of the drug available for inhalation. Optimally, this surface charge can be reduced by washing with detergent and subsequent drying. Alternatively, the surface charge can be reduced by fire of several puffs into the spacer, although this step will result with drug misspend (Wildhaber et al., 2000).

Table 4. Key recommendations regarding an optimal usage of inhaler devices

\section{Breathing slowly with full lung capacity}

2. Holding the breath after inhalation

3. Using a spacer or face mask

4. The use of a face mask is critical to the efficacy of aerosolized drug delivery in infants and young children

5. Proper cleaning of both the inhaler and the spacer

6. Adherence to the pharmacotherapy even when symptoms are improved

7. Establishment of a asthma management plan 
Table 5. Adverse reactions and events associated with asthma therapy

Adverse reactions associated with inhaled corticosteroids are dose-dependent. All of the corticosteroids show relatively few adverse reactions when are used via inhalation

Inhaled corticosteroids and in low to medium doses. Oropharyngeal disposition may result with dysphonia, oral candidiasis and cough. Systemic adverse reactions are associated with systemic use of corticosteroids and include adrenal suppression, immunosuppression and susceptibility to infections, Cushing syndrome, hyperglycemia, bone loss, skin atrophy and discoloration, cataract, temporarily slow growth, psychiatric disorders etc.

Although the mechanism by which $\beta_{2}$-agonists may cause cardiac adverse effects is insufficiently known, there is a risk of direct cardiac toxicity by stimulation of the $\beta 1$ -

$\beta_{2}-$ agonists adrenergic receptors, that occurs when these drugs are used in high doses. Asthma worsening may be masked as $\beta_{2}$-agonists provide quick acute symptoms relief, and subsequent nonadherence to inhaled corticosteroids use which are indicated to treat the bronchial edema and excessive mucus secretion (that follow an asthma exacerbation)

The use of high doses of teophylline may cause tremor, anxiety, medium caffeine -

Teophylline like CNS stimulation, headache, nausea etc., whereas the use of supratherapeutic doses may cause cardiac arrhythmia, convulsions, cerebral ischemia. Children are particularly at great risk of a severe toxicity due to variation in drug metabolism and secondary changes in drug clirens, as a result of a febrile virus infection

Cromones are relatively safe. Most common adverse events include cough and metallic

Cromones taste in the mouth

Leucotriene modifiers are associated with fatigue, fever, abdominal pain, dyspepsia, Leucotriene modifiers headache, dizziness, influenza, nasal congestion, cough and elevated levels of alanine aminotransferase (ALT) and aspartate aminotransferase (AST)

\begin{tabular}{ll}
\hline $\begin{array}{l}\text { Anti - IgE monoclonal } \\
\text { antibodies }\end{array}$ & $\begin{array}{l}\text { Anti - IgE monoclonal antibodies are associated with susceptibility to colds, headache, } \\
\text { fever, sore throat and earache, abdominal pain, nausea and vomiting, nosebleed etc. }\end{array}$ \\
\hline Ipratropium & $\begin{array}{l}\text { Ipratropium may cause systemic adverse reaction such as urinary retention and } \\
\text { glaucoma }\end{array}$ \\
\hline
\end{tabular}

Administration of inhaled medicines in children aged $0-5$ years

Inhaled route of administration is of first choice in asthma management. But it is well documented that patients, especially young children often face with challenges in adopting the correct inhaler technique. Children need careful supervision while taking their inhaled medicines (e.g. at preschool age), especially when using a reliever for on-the-spot relief, if acute asthma symptoms appear. During an acute wheezing episode, more effective delivery of short-acting $\beta_{2}$-agonist to airways can be achieved via use of pMDI plus spacer, rather than with a nebulizer. Often, preschool children poorly coordinate inhalation and actuation, and they cannot use a pMDI correctly, without a spacer attached and face mask if needed. DPIs are ineffective for preschool children because their inspiratory air flow is inadequate (Price et al., 2013). The drug delivery to the lower airways is variable from day to day in preschool children, even when using a spacer attached to the inhaler device. These variations might explain fluctuations in effectiveness of medicines, even if the child's parents have been trained to use the device correctly. When using a spacer with face mask (e.g. for an infant or a child that is not able to use a mouthpiece), effective delivery of medicine to the airways depends on a tight seal around the face. Crying significantly reduces the drug delivery to lower airways. Face masks should not be used for inhaled 
corticosteroids, due to the risk of adverse effects, as a result of exposure to eyes and skin. Very often, poor inhaler technique may lead to increased risk of local adverse effects such as dysphonia, associated with inhaled corticosteroids. Another common mistake among patients taking inhaled corticosteroids is failure to rinse the mouth with water and spit after each dose, which increases the risk of oropharyngeal candidiasis, caused by deposition of the medicine in the mouth and larynx. When administering salbutamol for quick relief of acute asthma symptoms, it is recommended to fire one puff at a time into the spacer and have the child take $4-6$ breaths in and out of the spacer with lips still sealed around the spacer mouthpiece (tidal breathing). In children with asthma aged 2-7 years (not tested during an acute asthma episode), the required number of tidal breaths to inhale salbutamol adequately from a spacer has been estimated at 2 breaths for small-volume spacers, 2 breaths for a spacer made from a 500-mL modified soft drink bottle, and 3 breaths for a large spacer (Australian Asthma Handbook. v2.0).

Table 6. Common asthma treatment associated interactions

\begin{tabular}{|c|c|c|}
\hline Drug & Interacting drug or food & Interacting Disease \\
\hline Teophylline & $\begin{array}{l}\beta_{2} \text {-agonists, caffeine, cimetidine, ciprofloxacin, } \\
\text { erythromycin, isoniazid, oral contraceptives, } \\
\text { mexiletine, interferons, propranolol, diltiazem, } \\
\text { verapamil, alopurinol, lithium, carbamazepine, } \\
\text { rifampicin, cardiac glycosides, diuretics etc. }\end{array}$ & $\begin{array}{l}\text { gastroesophageal reflux disease, } \\
\text { renal failure }\end{array}$ \\
\hline$\beta_{2}-$ agonists & $\begin{array}{l}\text { Teophylline, corticosteroids, } \beta \text { blockers, adrenergic } \\
\text { blockers, tricyclic antidepressants, monoamine } \\
\text { oxidase inhibitors etc. }\end{array}$ & $\begin{array}{l}\text { cardiovascular diseases, } \\
\text { diabetes mellitus, } \\
\text { hepatic failure }\end{array}$ \\
\hline Corticosteroids & $\begin{array}{l}\text { Systemic corticosteroids } \quad \text { (carbamazepine, } \\
\text { barbiturates, rifampicin, anabolic steroids, thiazide } \\
\text { and loop diuretics, } \beta \text {-agonists, theophylline, oral } \\
\text { antidiabetic agents, insulin, antihypertensives, } \\
\text { anticoagulants, NSAIDs, oral contraceptives etc) } \\
\text { Inhaled corticosteroids (systemic corticosteroids, } \\
\text { alcohol, CNS depressants, antihistamines, oral } \\
\text { antidiabetic agents etc.) }\end{array}$ & hepatic failure \\
\hline Montelukast & $\begin{array}{l}\text { Carbamazepine, oxcarbazepine, phenobarbital, } \\
\text { azole antifungals, dexamethazone etc. }\end{array}$ & $\begin{array}{l}\text { hepatic failure, } \\
\text { diabetes mellitus }\end{array}$ \\
\hline Zafirlukast & $\begin{array}{l}\text { Warfarin, propranolol, teophylline, fentanyl, } \\
\text { aspirin, budesonide, carbidopa/levodopa, ephedrine } \\
\text { etc. }\end{array}$ & hepatic failure \\
\hline Omalizumab & $\begin{array}{l}\text { Corticosteroids, } \beta_{2} \text {-agonists, anticholinergic drugs, } \\
\text { micronutrients (zinc, chromium, selenium, copper, } \\
\text { vitamin E etc.) }\end{array}$ & malignancies \\
\hline Ipratropium & Glyceryl trinitrate (sublingual) & $\begin{array}{l}\text { supraventricular arrhythmia, } \\
\text { arterial fibrillation }\end{array}$ \\
\hline
\end{tabular}


Administration of inhaled medicines in children aged 6 years and over

School-aged children, when trained carefully regard inhaler technique, care and cleaning of inhalers and spacers (depending on the child's age, ability) are able to correctly use a range of inhaler types, (pMDI with spacers, breath-activated pMDI and DPI). For most children, an appropriate inhaler device of first choice is a pMDI plus spacer. Key recommendations regarding the optimal usage of inhaler device are summarized in Table 4.

\section{Identification and prevention of the potential and management of actual drug associated adverse events}

The high potential of drug interactions and adverse reactions/events associated with the pharmacotherapy, the existence of multiple comorbidities which potentially affect the therapeutic outcome and increase the medication toxicity, require the need of a well organized system of patient-centered pharmaceutical care in order to timely identify and address the pharmacotherapy associated problems and in that way improve treatment adherence for each patient individually. The most common adverse reactions associated with asthma drugs and common drug - drug interactions which occur during the asthma treatment are summarized in Table 5 and 6 (Cates et al., 2012; Hossny et al., 2016; Kersten et al., 2016; Snell, 1994).

\section{Conclusion}

Health care for patients who suffer from asthma has marked remarkable developments over the last 30 years, with improved understanding of the underlying diverse factors of the asthma leading to therapeutic advances and to improved outcomes. However, asthma remains common, incurable, chronic disease and the global prevalence continues to increase and the improvements in therapeutic outcomes remain to be stagnant in most economically developed countries. Given the social significance of asthma and the increasing childhood morbidity, future developments in asthma care as with other long-term conditions, requires the need of implementation of "individualized" approaches into health care practice.

Community pharmacists, as a well trained health care professional, are ideally positioned to contribute towards an appropriate treatment, therapy adherence, optimal asthma control, and improvement of the life quality of patients by adequate educations for parents about asthma as a disease and early recognition of exacerbation symptoms, selection of the right inhaler and education for correct inhaler technique and identification and management of drug related problems.

\section{References}

Almomani, B.A., Mayyas, R.K., Ekteish, F.A., Ayoub, A.M., Ababneh, M.A., Alzoubi, S.A., 2017. The effectiveness of clinical pharmacist's intervention in improving asthma care in children and adolescents: Randomized controlled study in Jordan. Patient Educ. Couns. 100(4), 728-735. Available at: https://doi.org/10.1016/j.pec.2016.11.002.

Australian Asthma Handbook. v2.0. Available at: https://www.asthmahandbook.org.au/\%20management/chi ldren. Last accessed: June, 2019.

Barrons, R., Wheeler, J., Woods, J.A., 2015. Opportunities for inhaler device selection in elderly patients with asthma or COPD. Patient Intelligence 7, 53-65. Available at: https://doi.org/10.2147/PI.S61200.

Benavides, S., Rodriguez, J.C., Maniscalco-Feichtl, M., 2009. Pharmacist involvement in improving asthma outcomes in various healthcare settings: 1997 to present. Ann. Pharmacother. 43(1), 85-97. Available at: https://doi.org/10.1345/aph.1K612.

Bhatt-Mehta, V., Buck, M.L., Chung, A.M., Farrington, E.A., Hagemann, T.M., Hoff, D.S., Larochelle, J.M., Pettit, R.S., Phan, H., Potts, A.L., Smith, K.P., Parrish, R.H.2nd., 2012. Recommendations for Meeting the Pediatric Patient's Need for Clinical Pharmacist: A Joint Opinion of the Pediatrics Practice and Research Network of the American College of Clinical Pharmacy and the Pediatric Pharmacy Advocacy Group. J. Pediatr. Pharmacol. Ther. 17(3), 281-290. Available at: https://doi.org/10.5863/1551-6776-17.3.281.

Bradley, C.L., Luder, H.R., Beck, A.F., Bowen, R., Heaton, P.C., Kahn, R.S., Mansour, M., Obszarski, S., Frede, S.M., 2003. Pediatric asthma medication therapy management through community pharmacy and primary care collaboration. J. Am. Pharm. Assoc. 56(4), 455-460. Available at: https://doi.org/10.1016/j.japh.2016.03.007.

Cates, C.J., Oleszczuk, M., Stovold, E., Wieland, L.S., 2012. Safety of regular formoterol or salmeterol in children with asthma: an overview of Cochrane reviews. Cochrane Database Syst. Rev. Available at: https://doi.org/10.1002/14651858.CD010005.pub2.

European Respiratory Society, 2019. Childhood asthma in: European Lung White Book. Available at: https://www.erswhitebook.org/chapters/childhoodasthma/. Last accessed: June, 2019.

Fraeyman, J., Foulon, V., Mehuys, E., Boussery, K., Saevels, J., De Vriese, C., Dalleur, O., Housiaux, M., Steurbaut, S., Naegels, M., De Meyer, G.R., De Loof, H., Van Hal, G., Van den Broucke, S., 2017. Evaluating the implementation fidelity of New Medicines Service for asthma patients in community pharmacies in Belgium. Res. Social. Adm. Pharm. 13(1), 98-100. Available at: https://doi.org/10.1016/j.sapharm.2016.02.001.

Global Asthma Network, 2014. The Global Asthma Report. Available at: http://www.globalasthmanetwork.org/publications/Global _Asthma_Report_2014.pdf. Last accessed: June, 2019.

Global Initiative for Asthma, 2006. Global Strategy for Asthma Management and Prevention 2006. Available at: https://ginasthma.org/wp-content/uploads/2019/01/2006GINA.pdf. Last accessed: June, 2019. 
Global Initiative for Asthma, 2015. Pocket Guide for asthma management and prevention in children 5 years and younger. Available at: https://ginasthma.org/pocket-guidefor-asthma-management-and-prevention-in-children-5years-and-younger/. Last accessed: June, 2019.

Global Initiative for Asthma, 2017. Pocket Guide for asthma management and prevention for adults and children older than 5 years. Available at: https://ginasthma.org/wpcontent/uploads/2017/02/wms-Main-pocketguide_2017.pdf . Last accessed: June, 2019.

Holgate, S.T., Thomas, M., 2017. Asthma, in: O'Hehir, R.E., Holgate, S.T., Sheikh, A. (Eds.), Middleton's Allergy Essentials. Elsevier Inc., 151-204. Available at: https://doi.org/10.1016/B978-0-323-37579-5.00007-6.

Hossny, E., Rosario, N., Lee, B.W., Singh, M., El-Ghoneimy, D., Soh, J.Y., Le Souef, P., 2016. The use of inhaled corticosteroids in pediatric asthma: update. World Allergy Organ. J. 9, 26. Available at: https://doi.org/10.1186/s40413-016-0117-0.

Ibrahim, M., Verma, R., Garcia-Contreras, L., 2015. Inhalation drug delivery devices: technology update. Med. Devices (Auckl). 8, 131-139. Available at: https://doi.org/10.2147/MDER.S48888.

Kersten, E.T., Koopelman, G.H., Thio, B.J., 2017. Concerns with beta2-agonists in pediatric asthma - a clinical perspective. Paediatr. Respir. Rev. 21, 80-85. Available at: https://doi.org/10.1016/j.prrv.2016.05.006.

Khassawneh, B.Y., Al-Ali, M.K., Alzoubi, K.H., Batarseh, M.Z., Al-Safi, S.A., Sharara, A.M., Alnasr, H.M., 2008. Handling of inhaler devices in actual pulmonary practice: metered-dose inhaler versus dry powder inhalers. Respir. Care. 53(3), 324-328.

National Asthma Education and Prevention Program, 2002.
Expert Panel report: Guidelines for the Diagnosis and Management of asthma. Available at: https://www.nhlbi.nih.gov/files/docs/guidelines/asthmafullr pt_archive.pdf. Last accessed: June, 2019.

Okelo, S.O., Bultz, A.M., Sharma, R., Diette, G.B., Pitts, S.I., King, T.M., Linn, S.T., Reuben, M., Chelladurai, Y., Robinson, K.A., 2013. Interventions to modify health care provider adherence to asthma guidelines: a systematic review. Pediatrics 132(3), 517-534. Available at: https://doi.org/10.1542/peds.2013-0779.

Pooripussakul, S., Riewpaiboon, A., 2013. Management of Childhood Asthma and Role of Pharmacist. Mahidol University Journal of Pharmaceutical Sciences 40(1), 1827.

Snell, N.J., 1994. Drug interactions with anti-asthma medication. Respir. Med. 88(2), 83-88.

The Inhaler Error Steering Committee, Price, D., BosnicAnticevich, S., Briggs, A., Chrystyn, H., Rand, C., Scheuch, G., Bousquet, J., 2013. Inhaler competence in asthma: Common errors, barriers to use and recommended solutions. Respir. Med. 107(1), 37-46. Available at: https://doi.org/10.1016/j.rmed.2012.09.017.

Turner, S., 2016. Predicting and reducing risk of exacerbations in children with asthma in the primary care setting: current perspectives. Pragmat. Obs. Res. 7, 33-39. Available at: https://doi.org/10.2147/POR.S98928.

Wildhaber, J.H., Waterer, G.W., Hall, G.L., 2000. Reducing electrostatic charge on spacer devices and bronchodilator response. Br. J. Clin. Pharmacol. 50(3), 277-280. Available at: https://doi.org/10.1046/j.1365-2125.2000.00251.x.

World Health Organization, 2017. Asthma [Fact Sheet]. Available at: https://www.who.int/news-room/factsheets/detail/asthma. Last accessed: June, 2019.

\title{
Фармацевтска грижа во третман на педијатриска астма: улогата на фармацевтот во аптека
}

\author{
Катерина Илиовска*, Зоран Стерјев, Александра Капедановска Нестроровска
}

\author{
Фармацевтски факултет, Универзитет „Св. Кирил и Методиј”, Мајка Тереза 47, \\ 1000 Скопје, Република Северна Македонија
}

Клучни зборови: астма, педијатриска популација, фармацевт, фармацевтска грижа

Астмата е едно од водечките хронични заболувања кај педијатриска популација што афектира 1 од 12 деца на школска возраст. Има значаен придонес на растечката преваленца на пропишана фармакотерапија кај оваа специфична група на пациенти. Симптомите што ги презентира педијатриската астма се често варијабилни. Фармакотерапијата е доминантен терапевтски пристап, а обезбедувањето на безбеден и ефективен третман претстаува предизвик за сите здравствени работници, вклучително и фармацевтите. Растечкиот глобален товар што го креира астмата ја наметнува потребата, но и ја нагласува значајноста на активното учество на фармацевтите во менаџментот на астма. Концептот на фармацевтска грижа е интегрален дел од целокупниот процес на здравствена грижа и ги вклучува сите аспекти на постигнување на оптимални терапевтски исходи и подобрување на квалитетот на живот на пациентите, преку промоција на рационална употреба на лекови.

Макед. фарм. билт., 66 (1) 15 - 24 (2020) 
Целта на овој труд е да се направи преглед на публикуваните податоци, нагласувајќи ја потребата за планирање и имплементација на фармацевтска грижа во третманот на педијатриска астма и сите значајни аспекти на менаџментот на болеста во аптека и клинички услови. 